\title{
China's Efforts in Sustainable Development: A Test Case for Nigeria's Environmental Sustainability Goals
}

\author{
Akubue Jideofor Anselm \\ Faculty of Environmental Sciences, Baze University, Abuja, Nigeria \\ Email: akjideofor@yahoo.com
}

How to cite this paper: Anselm, A.J. (2017) China's Efforts in Sustainable Development: A Test Case for Nigeria's Environmental Sustainability Goals. Modern Economy, 8, 770-790.

https://doi.org/10.4236/me.2017.85054

Received: February 28, 2017

Accepted: May 23, 2017

Published: May 26, 2017

Copyright $\odot 2017$ by author and Scientific Research Publishing Inc. This work is licensed under the Creative Commons Attribution International License (CC BY 4.0).

http://creativecommons.org/licenses/by/4.0/

\begin{abstract}
The drive by nations to attain economic and social developments adversely affects the ecological balance of the environment. The challenges of maintaining a balance in the state of the global environment have become the major focus of many governments and the committee of nations at large. The global tool for measuring Environmental Sustainability ranks China among the highest on the global ecological footprints. It shows that a country like the United States draws its place due to its large consumption per person, while China on the other hand draws its place largely due to its enormous population. The complex nature of this value with regards to the increasingly fragile worldwide environment, suggests that the old paradigms of growth cannot work for China where the available resources face critical challenges of sustainability. China therefore presents a paradigmatic test case for environmental sustainability studies. Nigeria on the other hand shares peculiarity with China as the largest country in Africa with regards to population. Though Nigeria is presently a low technology based economy, however, with its abundant natural resources and the vision to joining the league of emerging global economies, Nigeria faces increasing challenges with the management of its share of environmental pollution. This paper aims at identifying the various resource and environment related challenges facing the Chinese and the actions put in place towards achieving a cleaner environment as a model for addressing sustainable environment issues in emerging economies like Nigerian.
\end{abstract}

\section{Keywords}

Environment, China, Nigeria, Environmental Sustainability, Sustainable Development

\section{Introduction}

Nigeria is a fast growing third world country with a large population and econ- 
omy. With its approximately 184 million inhabitants, Nigeria is referred to as the most populous country in Africa and the seventh most populous country in the world. As at 2015, Nigeria is regarded as the world's 20th largest economy, worth more than $\$ 500$ billion and $\$ 1$ trillion in terms of nominal GDP and purchasing power parity respectively. It overtook South Africa to become Africa's largest economy in 2014. With its present status, Nigeria is considered to be an emerging market and is often listed among the next eleven economies set to become among the biggest in the world. However, with the big expectations of economic development come the challenges of environmental degradation.

The purpose of this study is to outline the dynamics associated with economic development and their impacts on the environment. It presents the environmental sustainability challenges often associated with economic development, using the Chinese experience as a case study for emerging economies like Nigeria. With poor awareness on the issues of environmental management, Nigeria is yet to make significant progress in the areas of environmental sustainability.

Sustainability in general terms, can be defined as the ability to maintain balance of a certain process or state in any system. In an ecological context though, sustainability is defined as the ability of an ecosystem to maintain ecological processes, functions, biodiversity and productivity into the future [1]. In recent times, sustainability has become a complex term that is applied to almost every system on Earth and is expressed in human organization concepts like; eco-cities, sustainable cities, and further into human activities and disciplines such as: sustainable environment, sustainable agriculture, sustainable architecture and renewable energy [2]. For humans to live sustainably, the Earth's resources must be used at a rate at which they can be replenished. However, according to recent data, there is now clear scientific evidence that humanity is living unsustainably, and that an unprecedented collective effort is needed to return human use of natural resources to within sustainable limits [3].

Ever since the 1980s, the idea of sustainable human well-being has become increasingly associated with the integration of economic, social and environmental spheres. In 1989, the World Commission on Environment and Development (the Brundtland Commission) articulated what has now become a widely accepted definition of sustainability which is stated thus: "to meet the needs of the present without compromising the ability of future generations to meeting their own needs" [4].

Recent definitions classify sustainability to be of three dimensions often taken to be: environmental, social and economic, known as the "three pillars" [5]. These can be depicted as three overlapping circles to show that they are not mutually exclusive and can be mutually reinforcing. According to English environmentalist and author Jonathon Porritt, "The economy is, in the first instance, a subsystem of human society which is itself, in the second instance, a subsystem of the totality of life on Earth. And no subsystem can expand beyond the capacity of the total system of which it is a part" [6]. For this reason, it is rational to place economy as the critical component of society in both cases is bounded by 
and dependent upon the environment.

Since the launch of its "Open Door" policy in 1978, China's economic growth has been remarkable. Over the last 15 years, the average rate of economic growth has been $10.1 \%$ per year [7]. China now has the second largest economy in the world. Large foreign direct investment and the increased role of market forces have facilitated the country's integration into the global economy. With reference to Jonathon Porritt's theory as mentioned above, the effects of China's rapid economic growth, industrialization and urbanization have generated high pressures on China's environmental conditions, with challenges to health and natural resources. However, the Chinese authorities having acknowledged the state of the deterioration of the environment are promoting more balanced patterns of development, using such ideas as harmonious society and scientific development. Their reactions to this included planning for national economic and social development with more emphasis on environmental management efforts, modern environmental legislation, strengthened environmental institutions, and higher priority to environmental and natural resources management. Despite these efforts, there still abound numerous challenges like in the resultant air pollution in some Chinese cities that reaches levels that are among the worst in the world, coupled with challenges in waste management, desertification, and nature/biodiversity protection.

This paper thus examines the progress made by China since the 1990's and evaluates the extent to which the country's domestic objectives and international commitments are being met, with interest on drawing a profile for the Nigerian sustainable environment objectives.

\section{China's Economic Development and the Impacts on the Environment}

China's economy which can be said is mostly energy driven has been on the rise since the 1980's. The use of energy and its associated environmental impacts in China reflects remarkable economic development over the past three decades. China's economic growth has resulted in per capita income in excess of $\$ 5000$ (on a purchasing power parity basis) thereby lifting several hundred million people out of poverty since 1978 [8], probably the most successful poverty-reduction program in history. However, while China has about $20 \%$ of the world's population, its GDP per capita is still low (with USD 6000 for China compared to USD 25000 for OECD countries at PPP 2000) and this is unevenly distributed across the country, resulting in wealthier coastal provinces and less-developed western provinces. In this light, large migrations from rural to the more prosperous urban have contributed to rapid urbanization which stands at $43 \%$ of the population. Statistics shows presently that China today manufactures one out of every three tons of steel produced globally, and the Chinese domestic market consumes approximately 90 percent of that production [9]. Evidently too, the emerging middle class in China for instance, drives a rapid increase in automobile ownership, as the Chinese car market now exceeds the German and Japa- 
nese markets and will likely pass domestic sales in the United States in coming years [10]. China's phenomenal economic growth developed substantial investments in its energy infrastructure. In the past twenty years, power generation has increased ten-fold, and the rate of growth in installed capacity continues to increase. For instance in 2006 alone, China installed 105 giga-watts all of new capacity, of which 90 percent was coal-fired. China has now become the second largest consumer of petroleum, and third largest net importer in the world. According to the IEA 2007, the total energy demand has increased substantially as the economy has expanded, although through two distinct phases in recent years. The energy intensity of economic output declined significantly from 1980 through 2001 with the energy to GDP ratio falling approximately 5 percent per year. This trend reversed over the 2001 to 2005 period, with energy intensity increasing nearly 4 percent per year. The development trend in China brought substantial economic gains; however, this has adversely affected the local and global environment.

With its rapidly growing economy and as the world's most populous nation, China faces great stresses on its resources and environment. Its environmental issues have often a strong international dimension, reflecting regional environmental interdependencies like trans-boundary air and water issues, regional seas pollution, desertification and global economic and environmental interdependencies. The environmental pressures and demand for energy and other resources associated with China's rapid economic development dramatically underlines questions about the environmental sustainability of current production and consumption patterns globally. One of the serious negative consequences of the China's rapid industrial development has been the consequential increase in air pollution, climate change and degradation of natural resources (see Figure 1).

China's polluted environment can be argued to be largely as a result of the country's rapid development and consequently a large increase in primary energy consumption, which is primarily provided by coal power plants [11]. Through this study, the significant environmental problems that pose the greatest challenges to China's sustainable environment which can be related to the Nigerian context are classified as follows:

- Industrial pollution;

- Desertification and river cessation;

- Water pollution;

- Air pollution;

- Greenhouse gas emissions;

- Conservation;

- Climate change.

\subsection{Industrial Pollution}

One of the most severe environmental problems of an industrialized economy is industrial pollution. This is usually brought about by many years of improper 


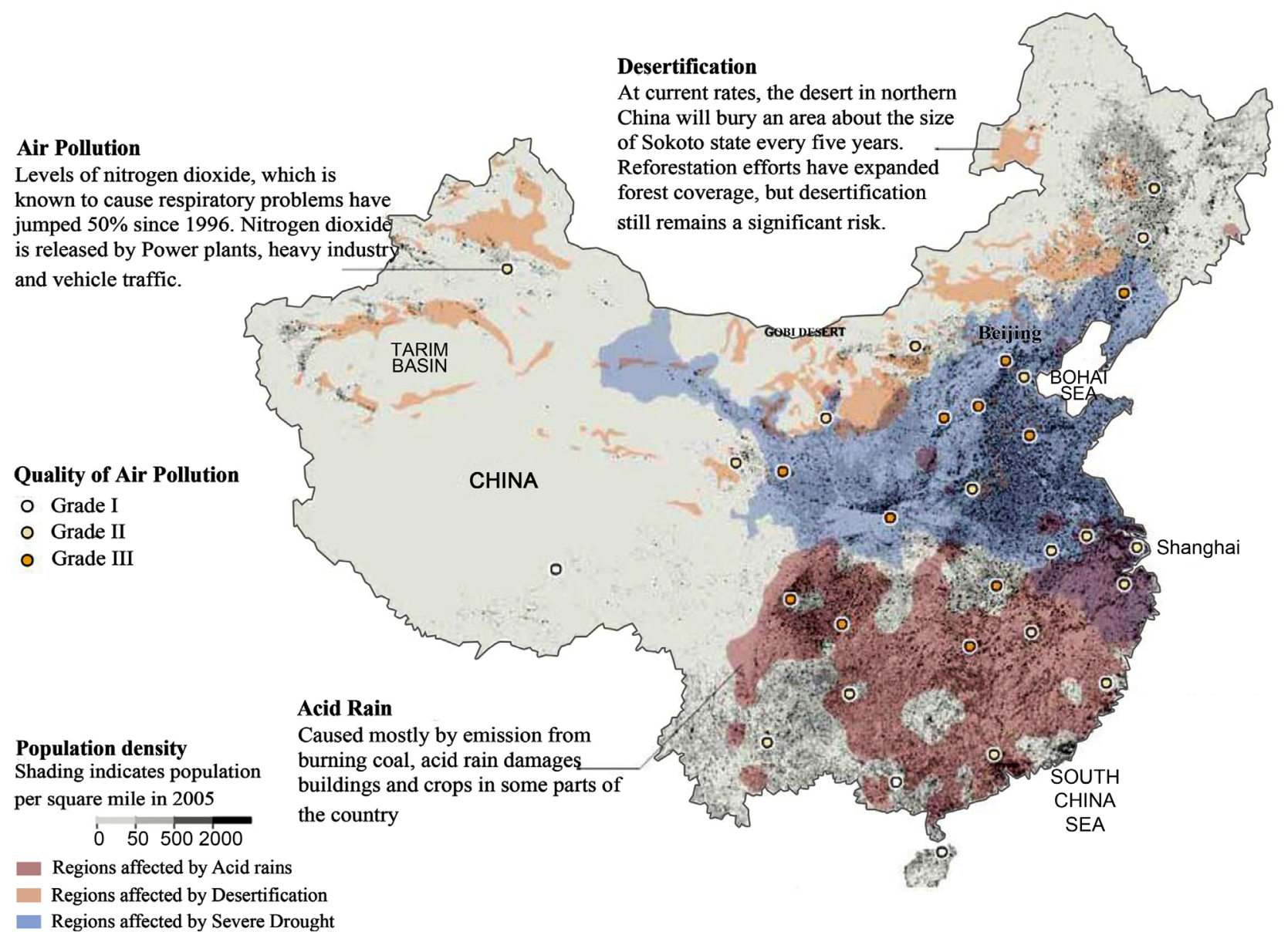

Figure 1. Environmental degradation in China [Data for the analysis sourced from Status of China environment Reports, 19992005].

industrial waste disposal and treatment over the years of industrialization. It is usually the case of improper government policies that determines the extents of failures in curbing the threats of industrial pollution. In the case of China, reports filed over the years by international and local activists contributed in challenging the government over this precarious situation and its effects in general. For instance according to the guardian.co.uk report filed on the China's Mother River (the Yellow River), claims that severe pollution caused one-third of the Yellow river unusable for agricultural or industrial use, due to factory discharges and sewage from fast-expanding cities [12]. Previously in 1997, the World Bank issued a report that targeted China's policy towards industrial pollution. The main summary points were likewise based on the severe effects of the industrial pollution on health and natural eco system [13]. Figure 2, shows the distribution of factories that use or produce chemicals, heavy metals and other potentially hazardous pollutants in China. The Yellow River Conservancy Committee, in 2007 surveyed more than 8384 miles of the river and reported that $33.8 \%$ of the river system registered worse than level five (according to criteria used by the UN Environment Program, level five is unfit for drinking, aquaculture, industrial use and even agriculture). The report stated that waste and sewage discharged 


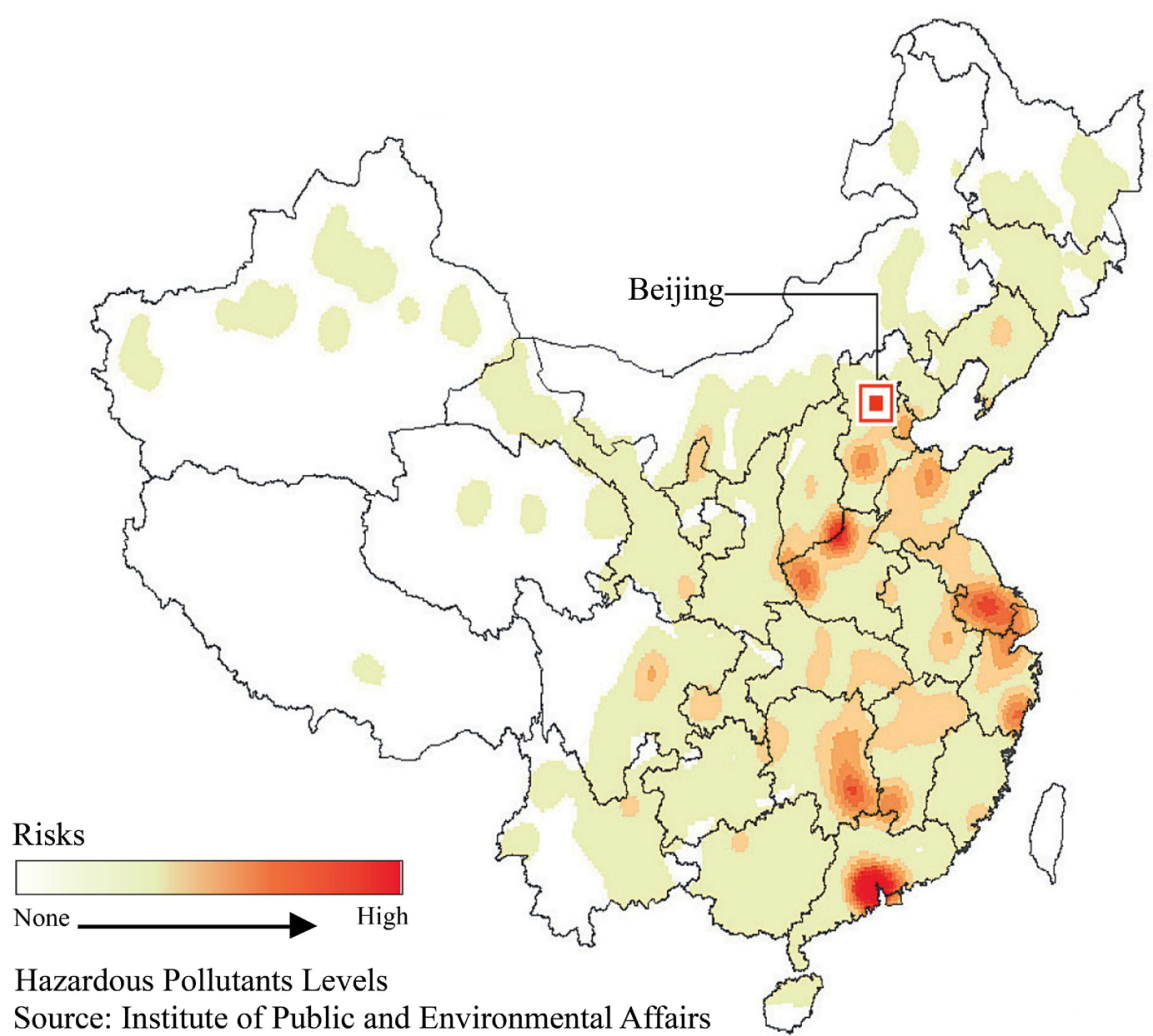

Figure 2. Map of China showing Factories that use or produce chemicals, heavy metals and other potentially hazardous pollutants.

into the system the previous year totaled 4.29 bn tones and according to it, industry and manufacturing made up $70 \%$ of the discharge into the river, with households accounting for $23 \%$ and just over $6 \%$ coming from other sources.

\subsection{Desertification and River Cessation}

Geologically, approximately $30 \%$ of China's surface area is desert land. However, China's rapid industrialization could cause this area to drastically increase. According to reports, the Gobi Desert in its northern region currently expands by about 950 square miles $\left(2500 \mathrm{~km}^{2}\right)$ per year. The vast plains in northern China used to be regularly flooded by the Yellow River. However, overgrazing and the expansion of agricultural land could cause this area to increase in the process of desertification. In the past 50 years, exploitation in the form of dams and other irrigation infrastructure has halted the river's natural course, threatening to dry up the entire river valley. The cessation of river flows and flow stoppages has surged since the 1980s due to increased water usage and waste. In 1997, the lower Yellow River did not flow 230 days out of the year, an increase of over $2000 \%$ since the 1988 event. Consequentially, increased erosion and sedimentation on the Loess Plateau, has made the river much less navigable by ship [14].

\subsection{Water Pollution}

Despite all of its technical efforts in regional water supply, China still faces 
enormous challenges in certified quality water supply according to the WHO standards. Almost $90 \%$ of underground water in its cities is affected by pollution out of which $80 \%$ of the rivers fail to meet standards for fishing [15]. It is also feared that $90 \%$ of its urban water bodies are affected to varying degrees [16] (see Figure 3). Consequent to these, sporadic water scarcity develops across the regions. For example, quality water scarcity in mostly northern China is a serious threat to sustained economic growth and has forced the government to begin implementing a large-scale diversion of water from the Yangtze River to these northern cities, including Beijing and Tianjin. Most water pollution issues in China are resultant from accumulated industrial pollution. The incident of November 2005 is well documented in this regard, as an explosion at a petrochemical plant in Jilin City caused a large discharge of nitrobenzene into the Songhua River. Levels of the carcinogen were so high that the entire water supply to Harbin city (population of 3.8 million) was cut off for five days between November 21, 2005 and November 26, 2005 [17].

\subsection{Air Pollution}

With its massive population, surging economy, and nascent car market, China has become the world's second largest consumer of petroleum products and among the biggest producers of carbon dioxide. Although it's environmental laws are among the strictest in the world, but enforcing these laws has been difficult in the past resulting in more polluted cities. According to its own evaluation, two-thirds of the 338 cities for which air-quality data are available are

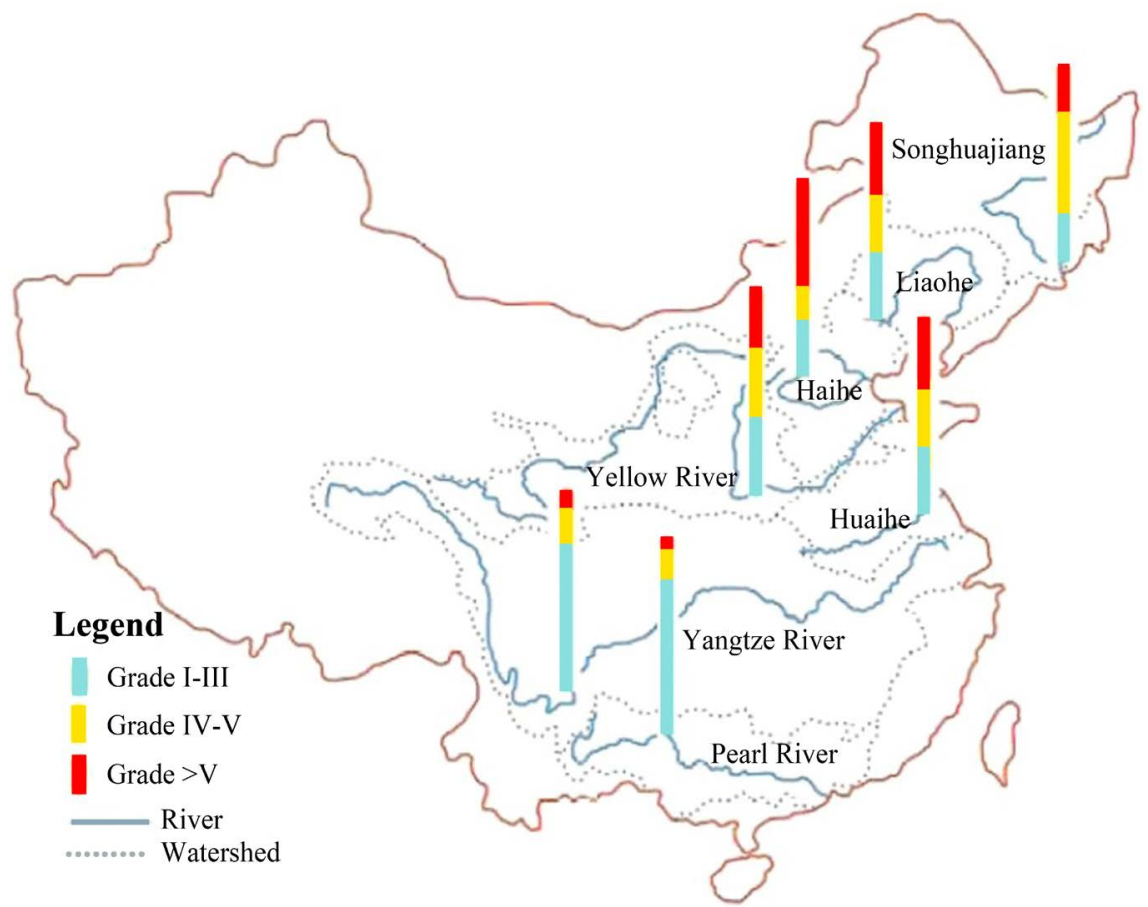

Figure 3. Water quality of 7 major rivers in China [Data sourced from China monitoring statistics 2005 . Among the 411 state monitoring stations in the seven rivers, $41 \%$ is classified I-III, 59\% classed IV or V]. 
considered polluted with almost two-thirds of them considered as moderately or severely polluted. Table 1 shows the air quality standard of China's cities from 1999 to 2005. According to the World Bank, the cities with the highest levels of particulate matter (PM2.5) are in China and they rank among the ten most polluted cities in the world by the measure of air quality standards [18]. Figure 4 shows the levels of particulate matter concentration in China's provinces.

\subsection{Greenhouse Gas Emissions}

Rapid development and reliance on coal to power developing economies is often identified as responsible for the dramatic increase in carbon dioxide emissions. For instance, in 1980, China's carbon dioxide emissions from fossil fuel combustion comprised 8 percent of global emissions. This increased to 10 percent by 1990, and advanced to 12 percent by 2000 . Figure 5 shows different forecast

Table 1. China cities' air quality standards from 1999 to 2005 (in \%).

\begin{tabular}{cccccccc}
\hline Air Quality Standards & 1999 & 2000 & 2001 & 2002 & 2003 & 2004 & 2005 \\
\hline $\begin{array}{c}\text { Grade II } \\
\text { (up to international standard) }\end{array}$ & 33 & 37 & 34 & 36 & 42 & 39 & 52 \\
Grade III & 26 & 30 & 33 & 34 & 31 & 41 & 38 \\
Worse than Grade III & 41 & 33 & 33 & 28 & 27 & 20 & 10 \\
\hline
\end{tabular}

Source: Status of China Environment Reports, 1999-2005.

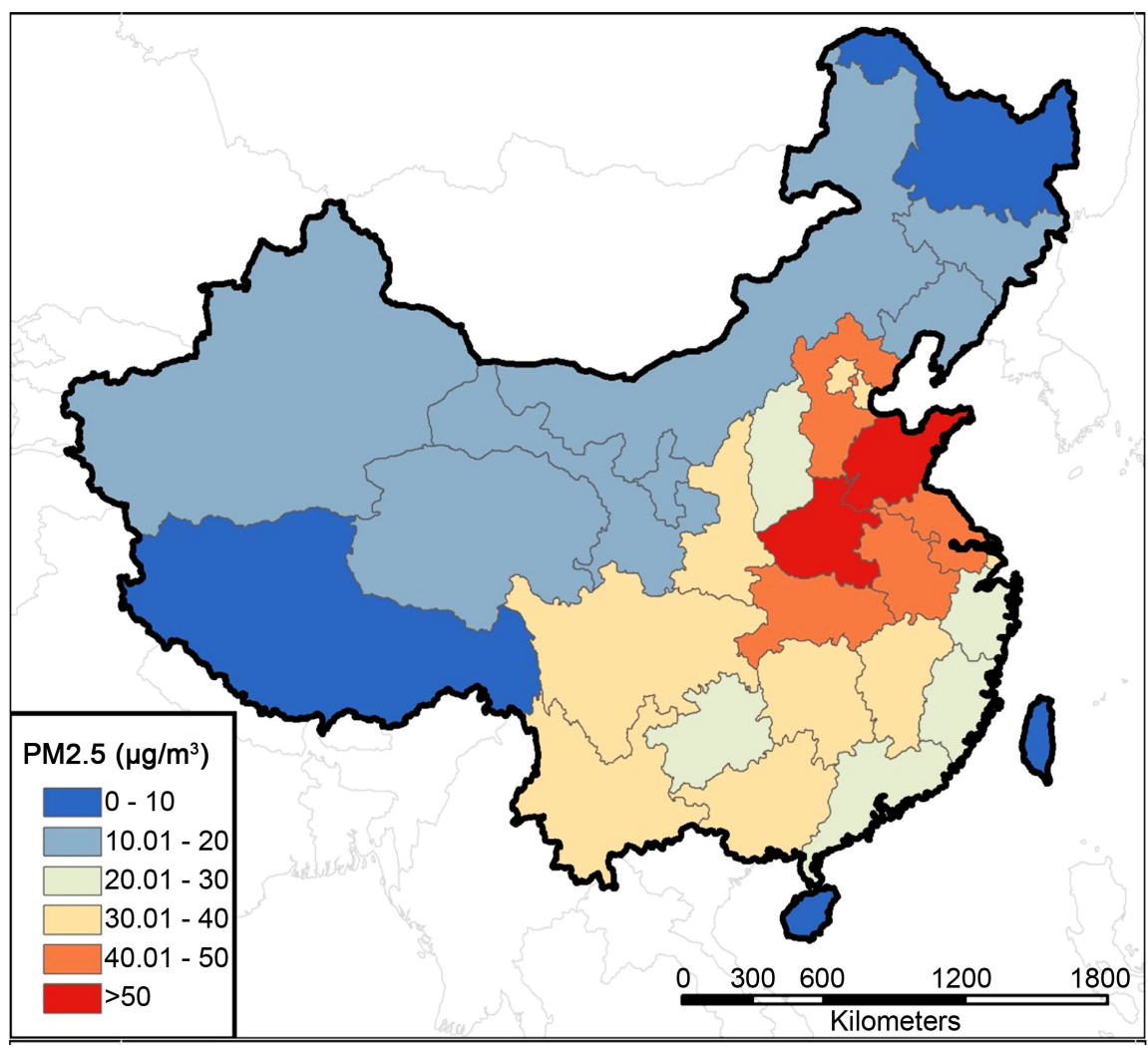

Figure 4. Average fine particulate matter concentration (PM2.5) to which provincial populations are exposed in China. 


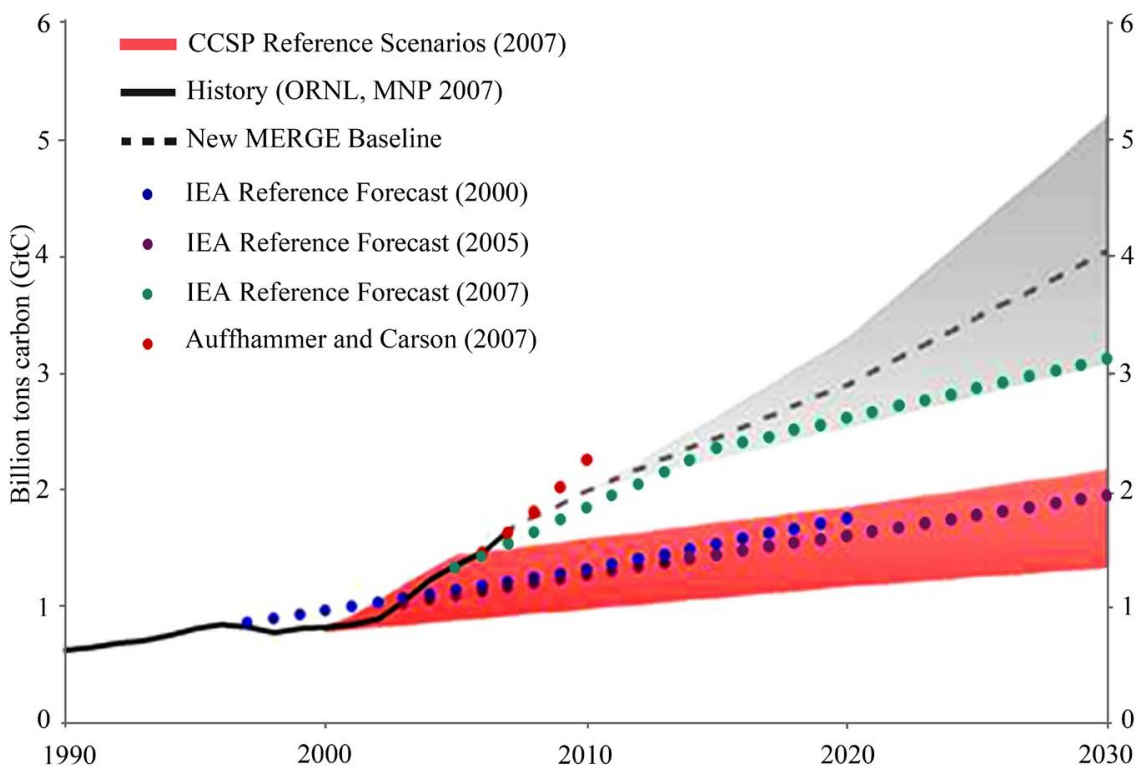

Figure 5. Forecast of China's carbon emission [19].

levels from various scenarios up to 2030. While the Baseline (i.e. businessas-usual) projections of growth in China's emissions in the near to mediumterm (e.g. through 2030) have until very recently been modest, the IEA estimates may still be underestimating China's potential growth. As seen in Figure 5, Auffhammer and Carson gave econometric forecasts of China's emissions path through 2010 using a province-level dataset up to 2004 and applying a variety of alternative model structures. The models with the best dynamic fit to the sample data indicate the potential for annual fossil fuel emissions to reach 2.25 billion tons of carbon (GtC) by 2010, a sharp increase from the Netherlands Environmental Assessment Agency's (MNP) reported total of $1.65 \mathrm{GtC}$ for 2007. This estimate for 2010 is almost double the IEA's 2005 forecast of $1.25 \mathrm{GtC}$ for that year, and significantly larger than the linearly interpolated 2010 level of $1.87 \mathrm{GtC}$ from the 2007 forecast. Thus growth in China is so rapid that it is difficult to predict emissions.

With the accelerated economic growth in this decade, and the reversal of the trend in improving energy efficiency, China's carbon dioxide emissions have taken off and passed that of the US emissions in 2006. In 2007, it's emissions of 1.83 gigatons of carbon alone comprised 23 percent of global carbon dioxide emissions, and these emissions exceeded that of the U.S. emissions by more than 15 percent in that year alone [20]. This recent acceleration in China's emissions growth reflects a variety of factors already enumerated above. However, the increasing role in international trade has also contributed to the growth in carbon dioxide emissions. In the case of embodied energy, the energy and carbon intensity of Chinese imports for instance, and their volume, is minute compared to the emission-intensity of Chinese imports. Even Chinese scholars have estimated that the embodied energy in net exports exceeded more than a quarter of all energy consumed in 2006 [21]. 


\subsection{Conservation Challenges}

Wild life and related conservation in China has become an international issue due predominately to the fate of the Giant Pandas in the region. Conservation has traditionally been of low priority, but progress has been made in recent years. The first wildlife refuge located at Dinghu Shan in Guangdong province, was created in 1956, since then, the number has grown to over seven hundred nature reserves covering almost six percent of the country. The government agencies managing these reserves have collaborated with a variety of external organizations since 1980, when the World Wide Fund for Nature (WWF) helped establish a giant panda conservation program. UNESCO counts ten Chinese reserves among its international network, a status which has encourage international funding for further conservation projects in mainland China. Moreover, driven by the growing international focus on its entry into the WTO, the Chinese government itself has shown a growing commitment to conservation in recent years.

\subsection{Climate Change in China}

Study indicates that by 2020 , and probably earlier, China is expected to replace the United States as the number one generator of global warming emissions [22]. However the Netherlands Environmental Assessment Agency in 2007, pronounced on the basis of an analysis of fossil fuel consumption including especially the coal power plants and cement production data, that China surpassed the United States as the world's largest emitter of carbon dioxide, putting out 6200 million tons, in comparison with America's 5800 million [23]. The major effects of global warming, which in its case include sea level rise and glacier retreat have already been witnessed in this region. This extensive condition has resulted in recorded acid rain falls on $30 \%$ of the country. China has been an active participant in the climate change talks and other multilateral environmental negotiations (locally and internationally), and takes environmental challenges seriously but is pushing for the developed world to help developing countries to a greater extent in tackling the climate change issues. It is a signatory to the Basel Convention governing the transport and disposal of hazardous waste and the Montreal Protocol for the Protection of the Ozone Layer, as well as the Convention on International Trade in Endangered Species and the Kyoto Protocol.

\section{Environmental Impact and Challenges of Sustainable Development}

According to the Environmental Sustainability Index (ESI 2005 shown in Table 2 ), which ranks countries based on such measures as health, governance, technology, and international cooperation, it places China 133rd out of 146 countries (with an ESI score of 38.6), Nigeria is placed at 98th out of 146 (with ESI score of 45.4). The ESI analysis is intended to quantify the likelihood that a country will be able to preserve valuable environmental resources effectively over the period of several decades. Conversely, it evaluates a country's potential to avoid major 
Table 2. Components of the 2005 environmental sustainability index.

\begin{tabular}{|c|c|}
\hline Component & Logic \\
\hline Environmental Systems & $\begin{array}{l}\text { A country is more likely to be environmentally sustainable to the extent } \\
\text { that its vital environmental systems are maintained at healthy levels, and } \\
\text { to the extent to which levels are improving rather than deteriorating }\end{array}$ \\
\hline $\begin{array}{c}\text { Reducing Environmental } \\
\text { Stresses }\end{array}$ & $\begin{array}{l}\text { A country is more likely to be environmentally sustainable if the } \\
\text { levels of anthropogenic stress are low enough to engender no } \\
\text { demonstrable harm to its environmental systems }\end{array}$ \\
\hline $\begin{array}{l}\text { Reducing Human } \\
\text { Vulnerability }\end{array}$ & $\begin{array}{l}\text { A country is more likely to be environmentally sustainable to the extent } \\
\text { that people and social systems are not vulnerable to environmental } \\
\text { disturbances that affect basic human wellbeing; becoming less } \\
\text { vulnerable is a sign that a society is on a track to greater sustainability }\end{array}$ \\
\hline $\begin{array}{l}\text { Social and Institutional } \\
\text { Capacity }\end{array}$ & $\begin{array}{l}\text { A country is more likely to be environmentally sustainable to the } \\
\text { extent that it has in place institutions and underlying social } \\
\text { patterns of skills, attitudes, and networks that foster } \\
\text { effective responses to environmental challenges }\end{array}$ \\
\hline Global Stewardship & $\begin{array}{l}\text { A country is more likely to be environmentally sustainable if it } \\
\text { cooperates with other countries to manage common environmental } \\
\text { problems, and if it reduces negative trans-boundary environmental } \\
\text { impacts on other countries to levels that cause no serious harm }\end{array}$ \\
\hline
\end{tabular}

environmental deterioration [24]. Another measure of environmental impact is the ecological footprint, which estimates the amount of biologically productive land used per capita. One source places the amount of such land at 2.0 hectares per person on planet earth [25]. The World watch Institute, by contrast, estimates China's footprint at 1.6 hectares and the United States' at 9.7 hectares [26].

With an enormous, and still growing, population, and an economy growing even faster, China's swelling environmental impact with regards to the per capita environmental impact is simply enormous. Undoubtedly, if China were to come close to the per capita environmental footprint of the most developed countries as shown in Table 3, its impact on the global environment imaginably would be catastrophic.

\subsection{Strategies for Achieving Environmental Sustainability in China}

China's comprehensive and modern set of environmental laws, together with its successive Five-Year Plans for National Economic and Social Development (FYPs) and Five-Year Environmental Plans (FYEPs), provide a high-quality framework for pursuing sustainable development and environmental progress. The effects of integrating the environment into the Five-Year Plans can be witnessed in the decrease of pollution and other factors that contribute to the general environmental issues as seen in Figure 6.

In December 2005 for instance, the State Council issued a decision for better implementing environmental policies. In April 2006, the Chinese Premier announced, in the sixth national environmental protection meeting, three new 
Table 3. China environmental impact forecast.

\begin{tabular}{ccccc}
\hline Year & $\begin{array}{c}\text { Population } \\
\text { (Billion) }\end{array}$ & $\begin{array}{c}\text { Affluence } \\
\text { (GDP per capita \$) }\end{array}$ & Technology & $\begin{array}{c}\text { Environmental } \\
\text { impact }(I) \text { (times) }\end{array}$ \\
\hline 2000 & $1.3-(1.0)$ & $800-(1.0)$ & 1 & 1.0 \\
2020 & $1.4-(1.1)$ & $3000-(3.75)$ & 1 & 4.1 \\
2050 & $1.5-(1.15)$ & $10,000-(12.5)$ & 1 & 14.4 \\
\hline
\end{tabular}

$I=$ PAT $($ Population $) \times($ Affluence-consumption per capita $) \times($ Technology $)=$ Environmental impact per unit consumption.

- Energy Consumption Per GDP decline by $20 \%$

- Total amount of major pollutants discharged reduce by $10 \%$

- Forest coverage from $18.2 \%$ to $20 \%$

- Comprehensive utilization of solid wastes increased to $60 \%$
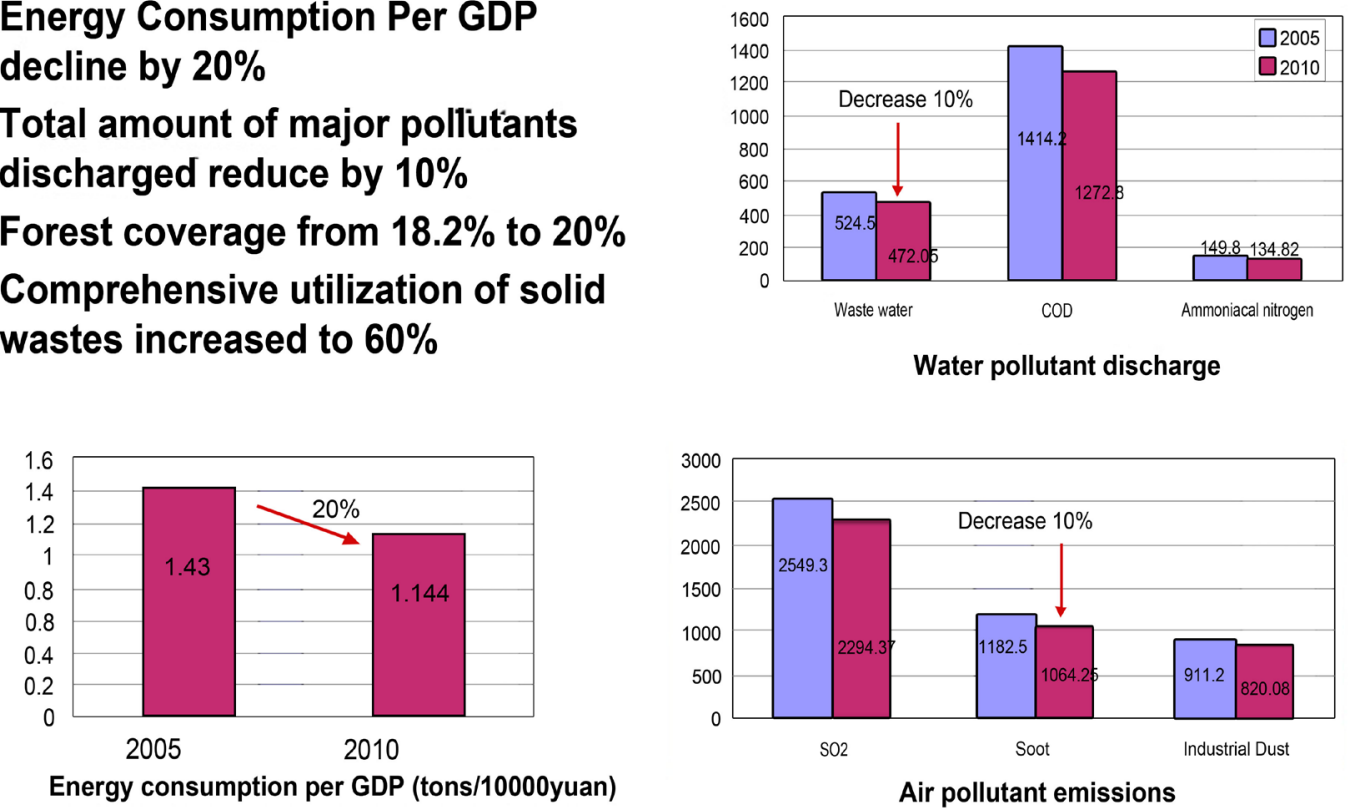

Figure 6. Positive effects of the FYP's as seen in the 11th FYP (2005-2010) [Source: SEPA, 2006].

policy directions, including: integrating environmental protection and economic decision-making on an equal footing, further decoupling pollutant emissions from economic growth, applying a mix of instruments to resolve environmental problems. The proposed directions and measures are being implemented and go a long way towards addressing the environmental policy implementation gap. In 2007, the Chinese government pronounced its plans to take sustainable development as a national strategy. By formulating the Program of Action for Sustainable Development in China in the early 21 st century, environmental protection has been incorporated into national development plan and programs. In the action plan, it specified priority to five measures for sustainable development in this regard as; clean production, developing circular economy, controlling pollutant discharge, promoting ecological preservation and protecting the environment according to law. The head of State Environment Protection Administration of China stated that China will further adjust and upgrade traditional industries like metallurgy, construction material, chemical industry, energy, textile and the light industry, quicken the phasing out of out-dated technologies and equipment and close down severely polluting and resource-wasting factories and mines according to law. Within this mandates, departments under the State 
Council have worked hard to support environmental policy implementation. A range of regulatory and economic instruments (e.g. pollution charges, user charges, emissions trading) and policy approaches that harness markets and public interest in the environment have been developed. Campaigns and award schemes to support implementation at the local level have been organized. There is evidence that local leaders in some of the richer provinces are responding to demands from the public for better environmental conditions, and are recognizing the benefits to the economy and the society. It is currently recorded that more than 8000 companies are registered under ISO 14000.

\subsubsection{Improvements in Air Quality}

Efforts made in the struggle for better air quality recorded certain levels of progress in China's environmental management process. For instance, it achieved improvements in ambient air quality (e.g. lowering the concentration of $\mathrm{SO}_{2}$ in urban areas and designated control zones) and in decoupling emissions of $\mathrm{SO}_{2}$, $\mathrm{NO}_{2}$ and $\mathrm{CO}_{2}$ from economic growth. The overall emission reduction targets for $\mathrm{SO}_{2}$, soot and dust from stationary sources set out in the 9th FYP (1996-2000) were met and surpassed; those for stationary source emissions of soot (-10\%) and industrial dust (-20\%) stipulated in the 10th FYP (2001-2005) are also likely to have been met. The legislative and regulatory framework was updated with the tightening of some emission limits, the introduction of total emission control, and the designation of special control zones (covering 39\% of the population). The rate of emission charges was trebled. A start was made with flue gas desulphurization at large emission sources. A nationwide air quality monitoring network was put in place. Energy policy and institutions (including a renewable energy law) were strengthened, and efforts to diversify energy sources had some success. In the domestic sector, the dependence on coal was reduced from $69 \%$ to $30 \%$ during 1990-2004. Concerning transport, environment-related efforts included the adoption of fuel-efficiency standards for light-duty passenger vehicles in 2004, the adoption of the various EURO standards for vehicle emissions at set dates, and the development of bus rapid transit systems in some cities.

\subsubsection{Improvements in Waste Management}

In the area of waste management, China significantly decoupled the generation of municipal and industrial waste from economic growth. Concerning industrial solid waste, the country met and surpassed the targets set out in the 9th and 10th FYPs with respect to recovery, reuse of waste material and safe disposal in landfills. China also stepped up its efforts to put in place an adequate legal framework for modern waste management by adopting a cleaner production law in 2003 and updating its 1995 waste law in 2004. A series of more specific regulations and standards for various types of waste, such as Medical waste, were adopted. A national program captioned "Construction Program of Hazardous Waste and Medical Waste Disposal Facilities" was put in place in 2003 to significantly increase capacity for treating hazardous and medical waste, and good 
progress was made consequently with the treatment of medical waste. The opening of the market to foreign waste management technology is also a positive signal for further improvement. Chinese authorities wish to curb the generation of all types of waste by fostering a high quality, low material intensity economic growth model. Indeed, given the rapid growth of its economy and of its imports, China's drive to reduce its material intensity parallels the drive to reduce its energy intensity. The concepts of the " $3 \mathrm{Rs"} \mathrm{(reduce,} \mathrm{reuse,} \mathrm{recycle)} \mathrm{and}$ of the "circular economy" are part of the country's 11th FYP. According to the China National Bureau of Statistics, by the end of 2005, the urban wastewater treatment capacity was 57.25 million tons a day, a progressive rise of 60 percent from 2002.

\subsubsection{Improvements in Natural Conservation}

In the area of nature and conservation, China has established a comprehensive legal framework for managing nature and biodiversity, which includes wildlife and marine protection as well as terrestrial and marine protected areas. China actively reports on its international commitments and also publishes annual state of the environment reports related to its internal goals and targets. Protected areas at the national, provincial, prefecture and county levels have been dramatically increased over the review period, and China has received international recognition for its wetlands, biosphere reserves, and natural and cultural heritage preservation programs. Outside of protected areas, ecological considerations have led to afforestation of large areas. New forestry initiatives have been taken to further develop shelter forests in arid, mountainous and coastal areas, to streamline forest management and to promote farm forestry on land sensitive to soil erosion. Along with the nation's ongoing efforts to check pollution, China's forest coverage has risen constantly for almost two decades, increasing the nation's contribution to the world carbon dioxide absorption. Various environmental protection programs within the country have begun to recognize the value of environmental outreach for alien species and endangered wildlife. With this comes a regular increase in the number of world heritage sites and Ramsar wetlands presently in China.

\subsection{Towards "Harmonious Society" and Environmentally Sustainable Development}

China has achieved some significant improvements to its environment during the recent years. And with its efforts towards achieving a sustainable development plan, includes promoting more balanced patterns of development, using concepts such as "harmonious society" and "scientific development". This initiative included planning for national economic and social development that covers environmental management efforts. Its overall Harmonious society initiative includes:

1) Integration of environmental concerns in economic decisions,

2) Integration of environmental and social decisions and

3) International Co-operation in addressing environmental challenges. 


\section{Environmental Governance and Progress in Environmental Policy Implementation}

Numerous avenues have been explored in mitigating China's environmental crisis, and implementing these reforms required an effective governance structure. The State Environmental Protection Administration (SEPA) is China's main environmental agency, roughly equivalent to the Environmental Protection Agency (EPA) in Nigeria. Historically, SEPA has been relatively weak, as priority has been given to development. At the top of the power structure, SEPA has been overruled by high-level agencies, while local governments, often empowered to enforce SEPA rulings, often have agendas of their own. Sources explains that, Over the past twenty years, economic bureaucracies as well as provincial and lower-level regional governments have been SEPA's chief organizational rivals because they believed that harsher environmental regulations would force coal mines to shut down, power plants to reduce energy production, logging industries to lay off workers, and, most importantly, localities to slow economic growth [27]. However, rapidity of development has often overruled environmental concerns. Facing severe environmental degradation, and in reaction to outside criticism, China has recently shown heightened awareness of environmental problems, with some government officials acting as strong advocates. Local groups have entered the environmental governance mix, as have international nongovernmental organizations (NGOs). Such NGOs as Friends of Nature and the World watch Institute are now working in conjunction with the Chinese government. Indeed, China now considers international expertise as crucial. There has been a sea of change in the formerly authoritarian and isolated approach to lawmaking in the Chinese government in this regard [28].

To express its level of commitment, a total of 256.6 billion yuan (see Figure 7 below) was poured into environmental protection in China in 2007, an increase of 87.7 percent from its 2002 budget for same, according to the China National Bureau of Statistics (NBS). Also, investment in environmental protection in 2006 accounted for 1.22 percent of the country's gross domestic product, compared with 1.14 percent in 2002. China's environmental protection industry has seen rapid growth in the past five years, according to the NBS. In 2006, the total turnover of the sector was 600 billion yuan while profits amounted to 52 billion yuan. The country has also seen a sound legal system for environmental protection since the 16th National Congress of the Communist Party of China convened in 2002. Over 50 regulations on environmental protection have been put in place since. Energy saving and environmental protection have become a key policy for the country. The government aims to reduce energy consumption per unit of GDP by 20 percent and major pollutant discharges by 10 percent in the 11th Five-Year Plan period from 2006-2010. In this light, the nation's power industry for example closed down all its coal-fired power plants, with a combined capacity of 50,000 $\mathrm{mw}$ in 2010. Also Desulfurizing facilities with a capacity of 104 million $\mathrm{kW}$ were put into operation at the nation's power plants. Now power-generating units with desulfurizing facilities account for around 30 percent of 


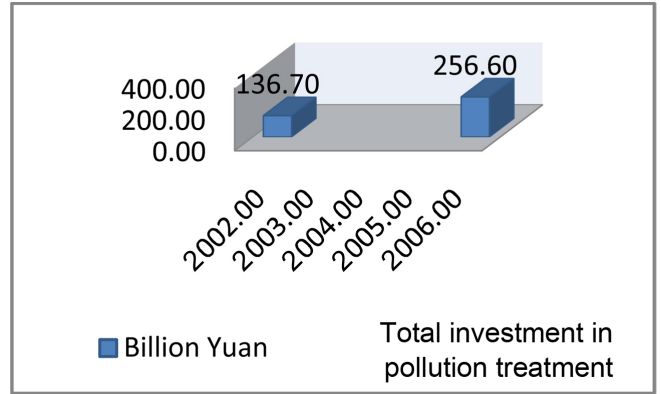

(a)
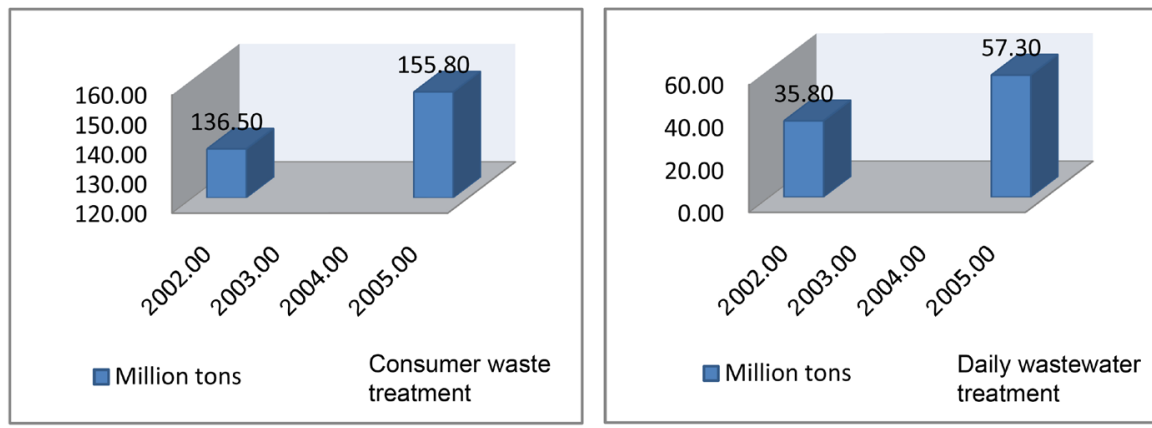

(b)
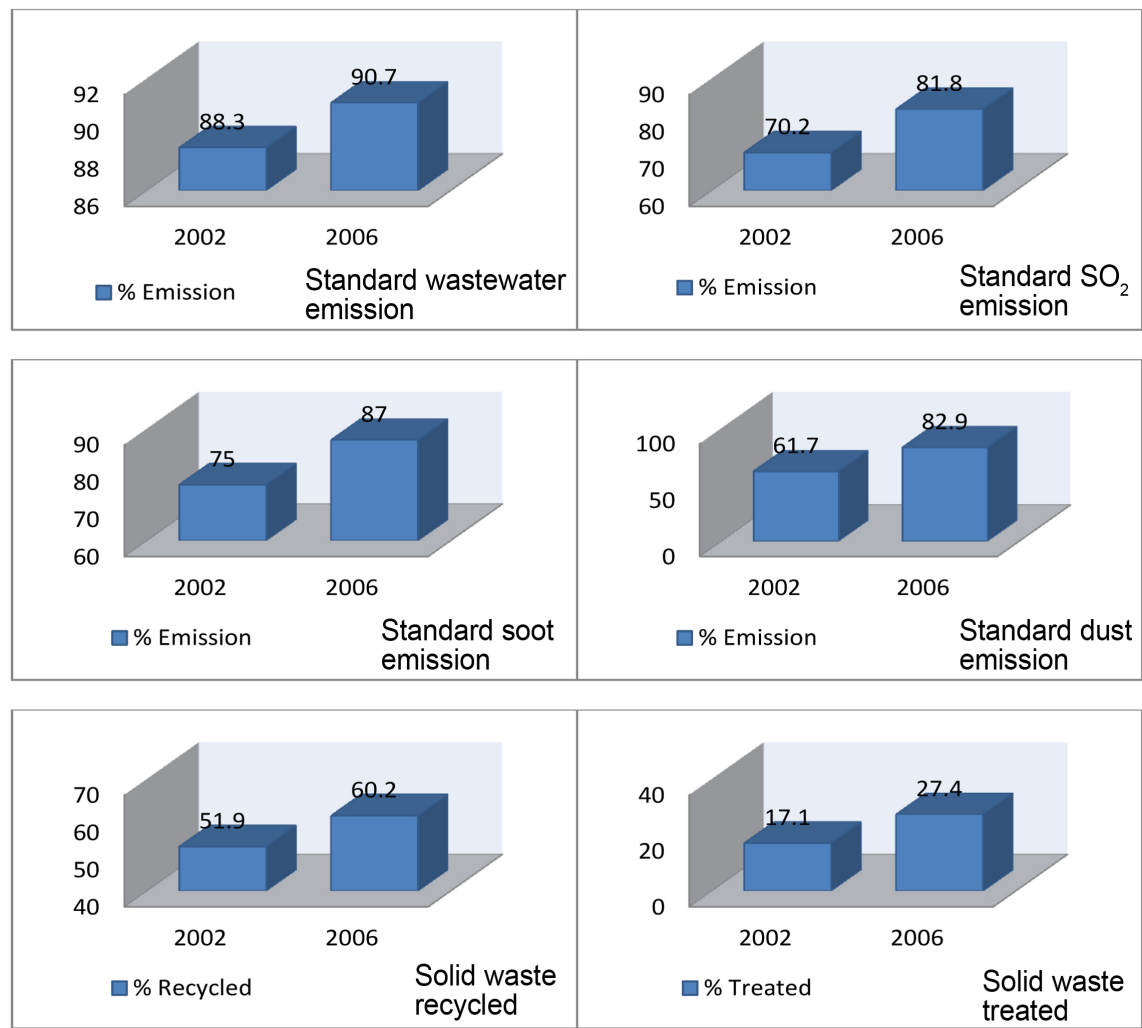

(c)

Figure 7. (a) Total investment in pollution treatment. (b) Improvement in Urban waste treatment. (c) Improvement in Industrial waste treatment.

the country's total power plants, compared with 12 percent as was the case in 2005. 


\section{The Nigerian Situation}

One can agree that many of Nigeria's environmental problems are characteristic of a developing country. With aggravated levels of poverty, low literacy rate (that impinges on environmental awareness), corruption and poor governance, Nigeria finds itself struggling with mostly basic social concerns, in so doing giving little or no consideration to such issues as the environment. Though with its high population situation, Nigeria yet enjoys a better environmental status than China at present. With most of its problems concentrated in the area of oil spillage, burning of toxic wastes and urban air pollution, Nigeria yet faces certain threat levels of environmental degradation. According to the Nation's encyclopedia data [29], in the early 1990s, Nigeria was among the 50 nations with the world's highest levels of carbon dioxide emissions, which totaled 96.5 million metric tons, a per capita level of 0.84 metric tons. However, data from the World Bank's West Central Africa Department, Industrial \& Energy operations Division [30], summarized the key environmental issues in Nigeria as follows:

1) Oil spillage and pollution;

2) Gas flaring and related air pollution;

3) Soil and mangrove degradation;

4) Rapid deforestation;

5) Desertification;

6) Threats to bio-diversity;

7) Poor waste management techniques.

As an oil producing economy, the major environmental challenges attributed to the oil industry are gas flaring and oil spillage. In the case of Nigeria, high frequency of oil spills in the Niger Delta is responsible for the environmental degradation of many communities. As a result of this, drinking water has been contaminated, and the ecosystem and soil composition have been altered irreversibly. Studies show that in the Niger Delta, a year's supply of food is often destroyed by only a minor leak of oil, debilitating the farmers and their families who depend on the land for their livelihood [31]. Observations indicates that since the twenty five years of the oil industry in Nigeria, there has been no concerned and effective effort on the part of the government to control environmental problems associated with the industry as the menace resultant from oil spillage continues. The other huge impact in the environment comes from Gas Flaring. Recently on the 2nd of February 2017, black soot covered the entire city of Port Harcourt, the capital city of the oil rich Rivers State. This incident which occurs frequently in the city and its environs is a reminder of the challenges to health and related dangers of air pollution in oil rich undeveloped nations.

According to Global Gas Flaring Reduction Partnership (GGFR), a World Bank-led organization comprised of oil companies, governments, and international institutions that are working to reduce gas flaring, a total of 147 billion cubic meters $(\mathrm{bcm})$ of natural gas was estimated flared in 2015 (see Figure 8) up from $145 \mathrm{bcm}$ in 2014 and $141 \mathrm{bcm}$ in 2013 [32]. According to the data from GGFR, the $147 \mathrm{bcm}$ of gas flared globally if used for combined power generation, 


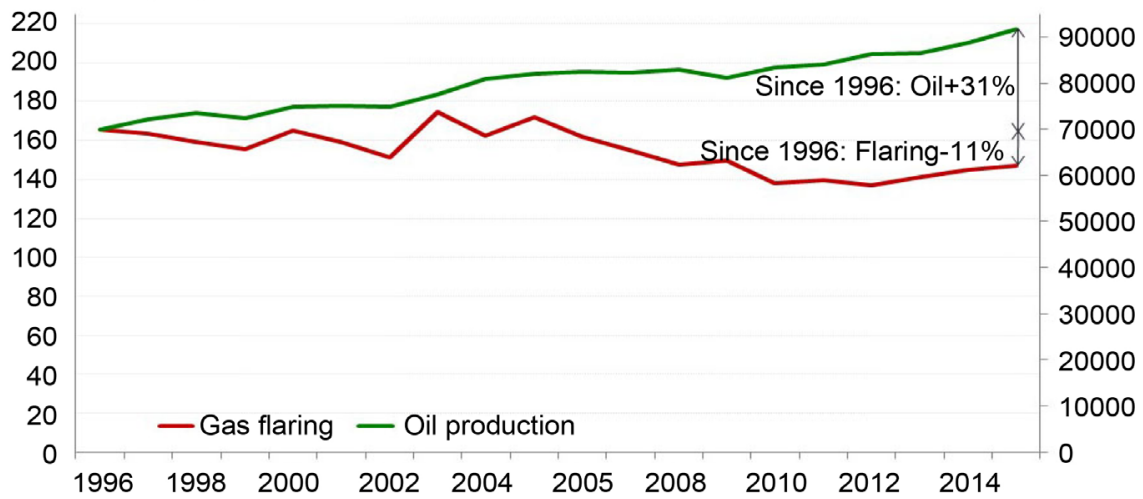

(a)

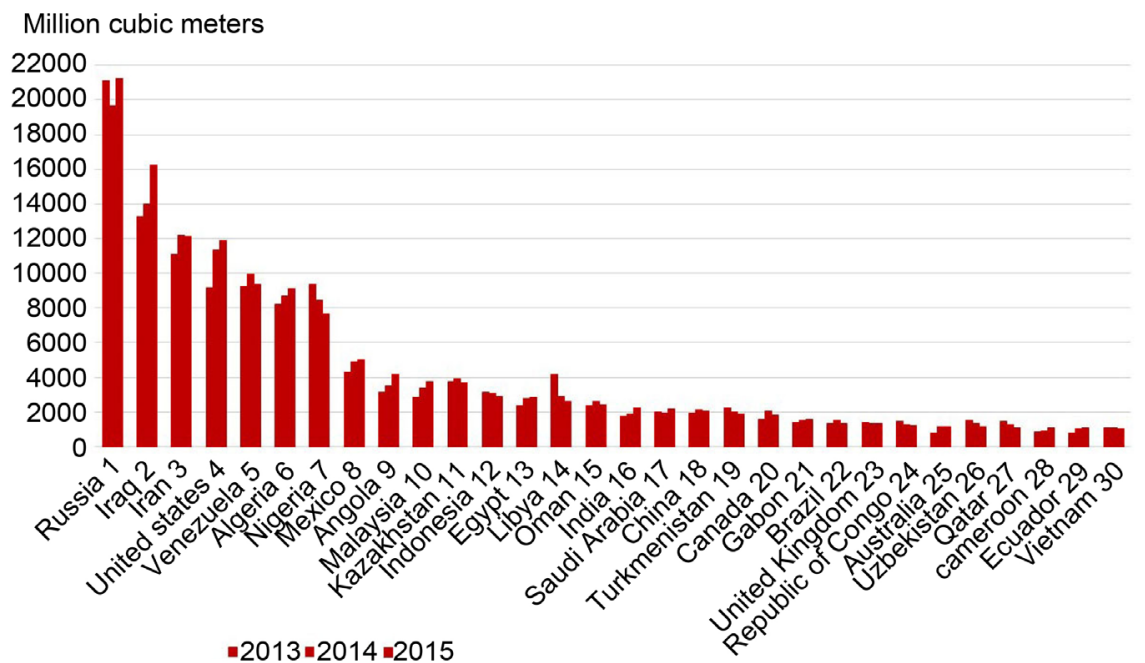

(b)

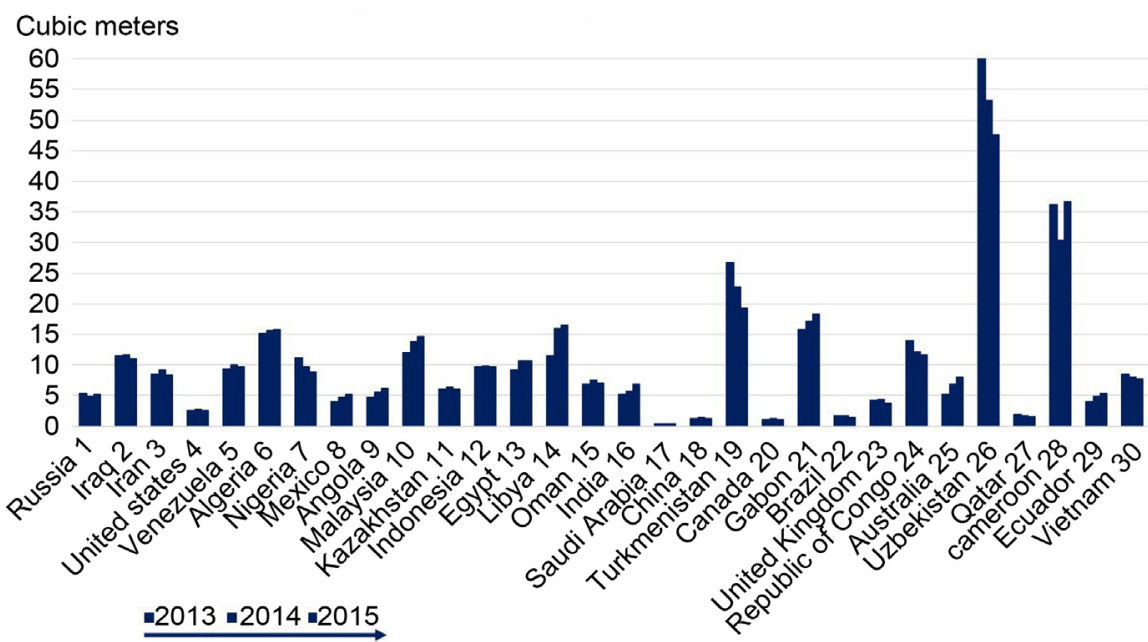

(c)

Figure 8. (a) Global gas flaring and oil production from 1996-2015. Flaring data was based on new satellite image system and calibration from 2013 (VIIRS satellite-Visible Infrared Imaging Radiometer Suite) [Source: BP/NOAA/GGFR]; (b) Ranking of top 30 gas flaring countries from 2013-2015. [Source: NOAA/GGFR]; (c) Gas flaring intensity by top 30 countries from 2013-2015. Graph shows cubic meters of gas flared per barrel of oil produced. [Source: GGFR, based on NOAA/GGFR/BP/EIA data]. 
could provide about 750 billion kWh of electricity, which is more than the African continent's current annual electricity consumption. This demonstrates that gas flaring is not only a hazard to the environment, but also a complete waste of natural resource that could be put to productive use or conserved if treated.

\section{Limitation of Study}

This study had challenges with identifying data collection centers on environmental statistics in Nigeria. This is attributed largely to the poor support for data collection by professionals in the related fields owing to inadequate understanding of the role of environmental statistics in the national development. The relevant agencies in the ministry of environment lack appropriate materials and equipment for data collection, processing, storage and dissemination, hence bureaucratic bottlenecks are used to impede effective data sourcing. Information available for this study was mainly sourced through NGO and academic platforms.

Research work in sustainable environmental issues cuts across the activities of many development agencies including the Federal and State Ministries of Environment, Federal Office of Statistics, Federal Ministries of Mines and Power, Petroleum Resources, Solid Minerals, Works, Agriculture and Rural Development, Water Resources, Health and also the Nigeria National Petroleum Company (NNPC), National Planning Commission, National Energy Statistics and Research Institutes down to the University linkage centers and NGOs. Improved coordination and collaboration within these relevant agencies and ministries will make the accessibility of information less stressful for scholarly interests.

\section{Conclusions}

This paper discussed the various challenges in achieving environmental sustainability, relative to the economic, social and environmental backdrops. By presenting the experiences of other industrialized economies like China, it lines out ideas that may be adopted in addressing sustainable environment issues.

Through this study and review of China's performance along the years, the following lessons can be presented for Nigeria's existing environmental sustainability plans especially with regards to the overall challenges in its population management, economic development and environmental goals:

1) Imbibing the concepts of "Harmonious society" in national and economic development plans, thereby extending the nation's economic base beyond the present petroleum and regional based centers hence, promoting more balanced patterns of development.

2) Stimulating the place of Sustainable environment development as a national strategy according to law. This initiative includes planning for national economic and social development that covers environmental management efforts and to encompass:

a) Integration of environmental concerns in economic decisions and

b) Integration of environmental in social decisions. 
c) Proper environmental Governance in Environmental policy implementation.

3) International co-operation in addressing environmental challenges and inculcating such initiatives as clean production, controlling pollutant discharge and promoting ecological preservation.

\section{References}

[1] Regional Ecosystem Office, REO (1995) Ecosystem Analysis at the Watershed Scale. Federal Guide for Watershed Analysis, 2, 25.

[2] Environmental Design Library (2009) Green Design; Sustainable Architecture Resources. http://lib.berkeley.edu/ENVI/GreenAll.html

[3] World Resources Institute. (2005) Millennium Ecosystem Assessment; Ecosystems and Human Well-Being: Biodiversity Synthesis. Summary for Decision-Makers, 116.

[4] United Nations General Assembly (1987) Report of the World Commission on Environment and Development: Our Common Future. Development and International Cooperation, General Assembly, Annex to Document A/42/427.

[5] United Nations General Assembly (2005) World Summit Outcome. General Assembly, Resolution A/60/1.

[6] Porritt, J. (2006) Capitalism as If the World Mattered. Earthscan, London, 46.

[7] OECD (2006) Working Party on Environmental Performance. Environmental Performance Review of China, Beijing, 2.

[8] United Nations Development Programme UNDP (2005) China Human Development Report. 29-45.

[9] Houser, T., Bradley, R., Childs, B., Werksman, J. and Heilmayr, R. (2008) Leveling the Carbon Playing Field: International Competition and U.S. Climate Policy Design. Peterson Institute for International Economics and the World Resources Institute, Washington DC, 17.

[10] International Energy Agency, IEA (2007) World Energy Outlook 2007: China and India Insights. International Energy Agency, Paris, 245-428.

[11] America's Most Polluted Cities (2006). http://www.forbes.com/logistics/2006/03/21/americas-most-polluted-cities-cx_rm_ 0321 pollute.html

[12] Branigan, T. (2008) One-Third of China's Yellow River Unfit for Drinking or Agriculture; Factory Waste and Sewage from Growing Cities Has Severely Polluted Major Waterway. http://www.guardian.co.uk/environment/2008/nov/25/water-china

[13] Dasgupta, S., Hua, W. and Wheeler, D. (1997) Surviving Success: Policy Reform and the Future of Industrial Pollution in China. The World Bank, 1.

http://econ.worldbank.org/external/default/main?pagePK=64165259\&piPK=641654 21\&theSitePK=469372\&menuPK=64216926\&entityID=000009265_3971229181112

[14] Ratliff, E. (2003) The Green Wall of China. Wired Magazine. http://www.wired.com/wired/archive/11.04/greenwall.html

[15] Miao, H. (2006) China Battles Pollution amid Full-Speed Economic Growth. Chinese Embassy (UK). http://www.chinese-embassy.org.uk/eng/zt/Features/t274443.htm

[16] Water Environment Partnership in Asia (2009) State of Water Environmental Issues: China. http://www.wepa-db.net/policies/state/china/river.htm

[17] BBC (2005) China City Water Supply to Resume. 
http://news.bbc.co.uk/2/hi/asia-pacific/4475096.stm

[18] World Bank (2007) World Development Indicators: Air Pollution http://siteresources.worldbank.org/DATASTATISTICS/Resources/table3_13.pdf

[19] Blanford, G.J., Richard G.R. and Thomas, F.R. (2008) Global $\mathrm{CO}_{2}$ Stabilization Implications of Revised Growth Projections for China. NOTA DI LAVORO, 68, 3.

[20] Netherlands Environmental Assessment Agency (2008) Global $\mathrm{CO}_{2}$ Emissions: Increase Continued in 2007. http://www.mnp.nl/en/publications/2008/GlobalCO2emissionsthrough2007.html

[21] Jiahua, P., Chen, Y., Zie, L. and Zheng, Y. (2007) Energy Embodied in Goods in International Trade in China: Calculation and Policy Implications. International Climate Change Regime: A Study on Key Issues in China, China Environmental Science Press, Beijing, 16-32.

[22] Poon, J., Casas, I. and He, C. (2006) The Impact of Energy, Transport, and Trade on Air Pollution in China. Eurasian Geography and Economics, 47, 1-17. https://doi.org/10.2747/1538-7216.47.5.568

[23] Netherlands Environmental Assessment Agency (2007) China Now No. 1 in $\mathrm{CO}_{2}$ Emissions; USA in Second Position.

http://www.pbl.nl/en/dossiers/Climatechange/Chinanowno1inCO2emissionsUSAin $\underline{\text { secondposition }}$

[24] Esty, D.C., Levy, M., Srebotnjak, T. and de Sherbinin, A. (2005) Environmental Sustainability Index: Benchmarking National Environmental Stewardship. Yale Center for Environmental Law \& Policy, New Haven. http://www.yale.edu/esi/

[25] Encyclopedia of Public Health (2007) Ecological Footprint. http://www.answers.com/topic/ecological-footprint?cat=health

[26] Flavin, C. and Gardner, G. (2006) China, India, and the new world order. State of the World 2006: Special Focus: China and India. Worldwatch Institute, Washington DC, 3-23.

[27] Zusman, E. and Turner, J.L. (2005) Beyond the Bureaucracy: Changing China's Policymaking Environment. China's Environment and the Challenge of Sustainable Development. M.E. Sharpe, New York, 121-149.

[28] Ferris, R.J. and Zhang, H. (2005) Environmental Law in the People's Republic of China: An Overview Describing Challenges and Providing Insights for Good Governance. China's Environment and the Challenge of Sustainable Development. M.E. Sharpe, New York, 66-101.

[29] Nation's Encyclopedia on Africa (2009). http://www.nationsencyclopedia.com/Africa/Nigeria-ENVIRONMENT.html

[30] Singh, J., Moffat, D. and Linden, O. (1995) Defining and Environmental Development Strategy for the Niger Delta. World Bank, West Central Africa Department, Industrial \& Energy operations Division, 54.

[31] Damilola, S.O. (2012) Legal and Sustainable Development Impacts of Major Oil Spills. Consilience: The Journal of Sustainable Development, 9, 1-15.

[32] World Bank (2015) Global Gas Flaring Reduction Partnership (GGFR) Data 20132015. http://www.worldbank.org/en/programs/gasflaringreduction 
Submit or recommend next manuscript to SCIRP and we will provide best service for you:

Accepting pre-submission inquiries through Email, Facebook, LinkedIn, Twitter, etc. A wide selection of journals (inclusive of 9 subjects, more than 200 journals)

Providing 24-hour high-quality service

User-friendly online submission system

Fair and swift peer-review system

Efficient typesetting and proofreading procedure

Display of the result of downloads and visits, as well as the number of cited articles Maximum dissemination of your research work

Submit your manuscript at: http://papersubmission.scirp.org/

Or contact me@scirp.org 